\title{
Development of Virtual Laboratory-Based of Learning to Improve Physics Learning Outcomes of High School Students
}

\author{
T. Abdjul*, N. E. Ntobuo, C. Payu \\ Department of Physics, Universitas Negeri Gorontalo, Indonesia
}

Received: 14 February 2019. Accepted: 9 May 2019. Published: 1 July 2019

\begin{abstract}
This study aims to develop virtual laboratory-based learning in physics subjects to improve the learning outcomes of high school students. This research is a research development with a 4-D model (define, design, develop, and dissemination). The results showed that the learning tools developed were categorized very well based on expert validation. Practical learning tools are used with an average value for the implementation of the learning process categorized very well and the average response of students to virtual laboratory based learning is very good. Student learning activities increased significantly after participating in learning. This research produces a valid, practical and effective learning tool by utilizing virtual laboratory media to improve student learning outcomes.
\end{abstract}

\begin{abstract}
ABSTRAK
Penelitian ini bertujuan untuk mengembangkan pembelajaran berbasis laboratorium virtual pada mata pelajaran fisika untuk meningkatkan hasil belajar siswa SMA. Penelitian ini adalah penelitian pengembangan dengan model 4-D (define, design, develop, dan diseminasi). Hasil penelitian menunjukkan bahwa perangkat pembelajaran yang dikembangkan berkategori sangat baik berdasarkan validasi ahli. Perangkat pembelajaran praktis digunakan dengan nilai rata-rata untuk keterlaksanaan proses pembelajaran berkategori sangat baik dan rata-rata respon siswa terhadap pembelajaran berbasis virtual laboratorium berkategori sangat baik. Aktivitas belajar siswa mengalami peningkatan yang cukup signifikan setelah mengikuti pembelajaran. Penelitian ini menghasilkan sebuah perangkat pembelajaran yang valid, praktis, dan efektif dengan memanfaatkan media laboratorium virtual untuk meningkatkan hasil belajar siswa.
\end{abstract}

Keywords: 4D; Laboratorium Virtual; Learning Tool.

\section{INTRODUCTION}

Physics is a branch of science which studies phenomena that can be proven mathematically and is supported by an experiment or practicum. Experiments to prove the phenomenon of physics is often carried out in a laboratory. The effective use of physics laboratories will be able to increase the success of physics learning activities.

According to Rahmiaty (2008), aspects needed to utilize the laboratory include the teacher's ability to use laboratory equipment and materials, complete laboratory infrastructure facilities, and effective laboratory mana-

\footnotetext{
*Correspondence Address:

Jalan Jendral Sudirman St. Nomor 6, Gorontalo 96128- Indonesia E-mail: tirtawaty@ung.ac.id
}

gement techniques. The limitations of tools and materials and laboratory facilities have the potential to be a barrier in conducting experiments in the laboratory. Moreover, there are some characteristics of physics concepts that are abstract, so they cannot be observed directly.

The above description is in line with the results of observations and interviews that have been conducted with a physics subject teacher in Gorontalo 1 High School on May 9, 2017. He stated that in carrying out the physics learning process of class XI teachers rarely involve students in experimental and observational activities live. This is because most of the instruments in the laboratory cannot function properly, the lack of availability of laboratory equipment, and there are some concepts of 
physics that cannot be practiced directly because they are abstract for example on sound topics with sub topics are sound sources and Doppler effects. It appears that the lack of availability of tools in the laboratory causes not all experiments can be carried out, so that teacher creativity is needed in creating an atmosphere of learning that is not much different from experiments conducted in laboratory (real practice), namely by using virtual laboratories so that experimental activities can still be carried out.

Virtual laboratories in general are one of the developments in information technology. Virtual laboratories have a function to overcome the limitations of laboratory facilities or overcome experimental activities that are too risky. Virtual laboratories are computer software systems that can be used to simulate effects or phenomena in learning that cannot be explained verbally. Virtual laboratories can change the functions of a real laboratory which is then implemented with applications that are contained on a computer.

Sutrisno (2012) argues that PhET Simulations are software that is ready to be operated, so it is as if students are doing practicums like practicums in actual laboratories. PhET Simulations is a practicum tool that was developed virtually by the University of Colorado, USA. PhET Simulations are widely used because they provide various models of science practicum, especially physics, so students can be invited to do practical work like in a real laboratory. This is intended to increase student motivation in learning. This is in line with the opinion of Tatli and Ayas (2012) who said that virtual laboratories as a supporting factor to enrich real experiences and motivate students to conduct experiments in the form of controlling materials and equipment, collecting data, conducting experiments interactively, and to prepare experimental reports and develop experimenting skills.

According to Nurhayati, Syarifah and Mutmainah (2016) that virtual laboratory learning by using PhET animation media is proven to be able to foster learning motivation and be effective in improving student learning outcomes. Virtual Laboratory Learning can simulate students' inquiry abilities so that physics learning outcomes obtained by students are in good categories (Sondang \& Chandra, 2014). Virtual Laboratory Learning can also reduce students' misconceptions in learning physics topics (Swandi \& Hidayah, 2014).

Based on a number of opinions that have been submitted, it can be concluded that a virtual laboratory is a series of computer programs that can visualize abstract and visible phenomena whose use seems to be in a real laboratory. Virtual laboratories can replace expensive and too dangerous experimental devices into safe and affordable activities in the learning process.

The use of virtual laboratory media does not mean that it can replace the actual role of the laboratory, but as an alternative solution to the incompleteness of real laboratory facilities and equipment in schools. Through virtual laboratories, teachers can explain abstract concepts that cannot be explained through verbal delivery (Sumargo and Yuanita, 2014). Virtual laboratories can be a place for experiments that cannot be done in conventional laboratories.

In order to achieve the learning objectives using the virtual laboratory media, the program must be designed in a learning tool that is relevant to the topic being taught. Some research results indicate that the use of virtual laboratories can improve student learning outcomes. Hermansyah and Herayanti (2015) research results show that learning by using a virtual laboratory can influence the improvement of students' mastery of abstract concepts. In addition, based on the results of research by Sumargo and Yuanita (2014), it was found that learning using a virtual PhET laboratory can improve students' understanding of concepts so that an increase in student grades.

Based on the results of the analysis of related articles, the results of field observations, and the facts faced by the authors, it is considered important to carry out a research oriented to the development of learning models based on virtual laboratories. The purpose of this research is to produce a valid, practical, and effective virtual laboratory-based physics learning tools.

\section{METHOD}

This research was carried out in Gorontalo 1 High School with the test subjects of the application of virtual laboratory-based learning tools were students of class XI odd semester of the 2016-2017 school year. This study is a development research using the 4D model proposed by Thiagarajan, Semmel, and Sammel (1974) which consists of four stages, namely Define, Design, Develop, and Disseminate.

The 4D development model was chosen 
because it has several advantages, namely 1) is the basis for developing learning tools (not learning systems), 2) the stages of implementation are divided in detail and systematically (Mademin, 2012). According to Sugiyono (2013), research and development methods are research methods used to produce certain products and test the effectiveness of these products.

The product developed in this study is a learning device that includes a syllabus, lesson plan (RPP), student worksheets (LKS), teaching materials and learning outcomes tests based on virtual laboratories. According to Trianto (2007) learning devices are devices used in the learning process in the form of: student books, syllabus, learning implementation plans (RPP), learning achievement tests, and learning media. The quality of the learning tools produced is based on the criteria proposed by Nieveen (1999) covering three aspects, namely validity, practicality, and effectiveness.

The instruments used in this study were (1) the validation sheet of the learning kit, (2) the observation sheet of the implementation of learning, (3) the observation sheet of student activity, (4) the test of learning outcomes, and (5) the questionnaire created with the aim of obtaining a response or responses from students to the learning model applied by the teacher during the learning process. The steps of this research activity are presented in Table 1.

Table 1. Steps of Research Activities

\begin{tabular}{|c|c|}
\hline Activities & Descriptions \\
\hline $\begin{array}{l}\text { Develop learning } \\
\text { tools (syllabus, les- } \\
\text { son plans, teaching } \\
\text { materials and THB) } \\
\text { by involving virtual } \\
\text { laboratory activities }\end{array}$ & $\begin{array}{l}\text { Analyzing theories and } \\
\text { learning models based on } \\
\text { virtual laboratories from } \\
\text { various references (books, } \\
\text { journals, relevant research } \\
\text { results) }\end{array}$ \\
\hline Expert judgment & $\begin{array}{l}\text { The device product devel- } \\
\text { oped was validated by two } \\
\text { experts to test its validity } \\
\text { and eligibility }\end{array}$ \\
\hline Limited trial & $\begin{array}{l}\text { Validated learning tools } \\
\text { were tested on a limited } \\
\text { sample, to students in } \\
\text { Class XI of the Gotong } \\
\text { Royong Vocational School } \\
\text { in Gorontalo }\end{array}$ \\
\hline $\begin{array}{l}\text { Revised models } \\
\text { based on limited trial } \\
\text { results }\end{array}$ & $\begin{array}{l}\text { Carry out revisions based } \\
\text { on limited trial results. }\end{array}$ \\
\hline
\end{tabular}

\begin{tabular}{ll}
\hline Implementasi model & $\begin{array}{l}\text { Carry out revision results in } \\
\text { class XI of SMA Negeri 1 } \\
\text { Gorontalo with 40 students } \\
\text { to see the effectiveness } \\
\text { of the developed learning } \\
\text { tools. }\end{array}$ \\
\hline Dissemination & Virtual laboratory-based \\
& learning tools will be ap- \\
plied to class XI high school \\
students in Gorontalo Prov- \\
ince and the results will be \\
published in national and \\
international seminars.
\end{tabular}

The qualities of the virtual laboratorybased learning tools resulting from this study are as follows.

\section{Validity}

The validation of learning tools was assessed by two validators, namely one lecturer in education and one subject teacher in Gorontalo 1 high school. Validation sheets to assess learning tools are intended to assess the syllabus, lesson plans (RPP), student worksheets (LKS), teaching materials, and learning achievement tests. The assessment aspects contained in the syllabus, RPP and LKS validation sheets include format, content, and language. teaching material validation sheets include aspects of content, presentation, and language; while the test validation sheet covers aspects of content and language. After being validated, the learning tools are then revised, and based on the results of the revision the validator gives a value (SV) to the learning tools that are adjusted to the assessment criteria according to Ratuman \& Laurens (2011) as listed in Table 2.

Table 2. Categories of Validation Results

\begin{tabular}{ll}
\hline Average Scores & Criteria \\
\hline $4,1 \leq$ SV $\leq 5,0$ & Very Valid \\
$3,0 \leq$ SV $\leq 4,0$ & Valid \\
$2,0 \leq$ SV $\leq 3,0$ & Quite Valid \\
$1,0 \leq$ SV $\leq 2,0$ & Less Valid \\
$0,0 \leq$ SV $\leq 1,0$ & Not Valid \\
\hline
\end{tabular}

\section{Practicality of Learning Devices}

Learning tools are considered practical if the respondent states that learning tools can be used in learning activities as indicated by the optimal score of learning performance and positive responses from students (Nieven, 1999). 


\section{Implementation of learning}

The aspects of evaluating the feasibility of learning are seen based on the scenarios contained in the lesson plan which consists of three stages, namely the preliminary stage, the core activities, and the closing stage. Analysis of the observation sheet of the implementation of learning using a percentage as proposed by Arikunto (2010). The percentage of performance is categorized based on the assessment categories mentioned in Table 2.

\section{Student Questionnaire}

Student questionnaire is used to see how students respond to the implementation of virtual laboratory-based learning. Student responses are measured using several indicators, namely feelings of pleasure, attention, interest, and student involvement in learning. Response categories are classified using the categories as proposed by Arikunto (2010) listed in Table 3.

Table 3. Student Response Categories

\begin{tabular}{lc}
\hline Categories & Scores \\
\hline Very Agree (SS) & 5 \\
Agree (S) & 4 \\
Doubtful (RR) & 3 \\
Less Agree (KS) & 2 \\
Not Agree (TS) & 1 \\
\hline
\end{tabular}

Data from the results of student questionnaires on learning activities were analyzed by calculating the percentage of students' answers.

\section{Effectiveness of Learning Tools}

The effectiveness of learning tools in this study is viewed from two aspects, namely learning activities and student learning outcomes (Nieven, 1999). The analysis for these two aspects is described as follows.

\section{Learning Outcomes Test (THB)}

Student learning outcomes measured in this study are cognitive learning outcomes which include aspects of understanding (C2), application (C3), analysis (C4), and synthesis (C5). THB data can be analyzed using the percentage formula as proposed by Arikunto (2010)

\section{Student learning activities}

Based on the learning steps contained in the lesson plans and worksheets, student activities observed in virtual laboratory learning include observing, questioning, exploring, associating, concluding, and communicating. The observations of student learning activities carried out by observers were analyzed using the percentage equation proposed by Arikunto (2010).

\section{RESULTS AND DISCUSSION}

The development of virtual laboratorybased learning tools begins with the define stage. The activity at this stage is to analyze the basic problems experienced by students and teachers in the learning process. Based on observations it has been found that in general there is no virtual laboratory-based learning device even though on the internet there are many virtual laboratory-based learning media that are easy to access. This virtual media has been proven to be able to improve student learning outcomes, overcome the lack of availability of laboratory equipment, and provide visual images on some physics topics that cannot be practiced directly related to their abstract characteristics.

The design phase or the design of this tool is carried out based on the results of observations made. Learning tools developed are learning tools based on virtual laboratories, namely syllabus, lesson plans, teaching materials, worksheets and learning achievement tests. The learning scenario implemented by the teacher in learning according to the syllabus and lesson plans is an inquiry learning model adopted from the Syah (Fathurrohman, 2015).

Define and design phase results in the initial design of a learning tool which is then validated and tested on limited classes. Validation is the first step in the develop phase. The results of expert validation in the form of validation scores, corrections and suggestions are then used as a basis for revising and refining the learning tools.

The last step is disseminaton. The results of this study were disseminated to the eleventh grade students of Gorontalo Province High School. In addition, the results of the study were disseminated through national seminars. Following are the results of validation and limited trials of the application of virtual laboratorybased learning.

\section{Learning Tools Validation Results}


The validity of the virtual Laboratorybased learning tools that have been developed is obtained from the results of the validation conducted by 2 validators as in Table 4 .

Table 4 shows that the results of validation for syllabus, lesson plans, worksheets and teaching materials categorized as very valid while THB is classified in the valid category. As per the validator's assessment, learning tools can be used with minor revisions. The results of the validation of virtual laboratory-based learning tools are presented in Table 5.

Based on the results of the validation in Table 5, it can be concluded that all learning tools based on laboratory, especially virtual sound concepts that have been developed, reach a very valid category. This means, learning tools developed are feasible to be applied to learning physics, to improve student learning outcomes. This is in line with the results of research conducted by Chodijah, Ahmad \& Ratna (2012) that to improve physics learning in the classroom, learning devices such as syllabi, lesson plans, modules and worksheets are needed to support student activities. After the virtual laboratory-based learning tools are validated, the activity is continued with limited trials to obtain data on the practicality and effectiveness of virtual laboratory-based learning tools.

Table 4. Average Validation Results

\begin{tabular}{|c|c|c|c|c|}
\hline \multirow{2}{*}{ Learning Tools } & \multicolumn{2}{|c|}{ Percentage of eligibility (\%) } & \multirow{2}{*}{$\begin{array}{l}\text { Average percentage of } \\
\text { validity }(\%)\end{array}$} & \multirow{2}{*}{ Categories } \\
\hline & Val. 1 & Val. 2 & & \\
\hline Syllabus & 4.15 & 4.83 & 4.50 & SV \\
\hline Lesson Plan & 4.58 & 4.90 & 4.74 & SV \\
\hline Learning Materials & 4.79 & 4.90 & 4.84 & SV \\
\hline Students Worksheets & 4.58 & 4.86 & 4.72 & SV \\
\hline THB & 4.00 & 4.05 & 4.00 & $\mathrm{~V}$ \\
\hline
\end{tabular}

Table 5. Validation Results of Learning Tools on Sound Concepts

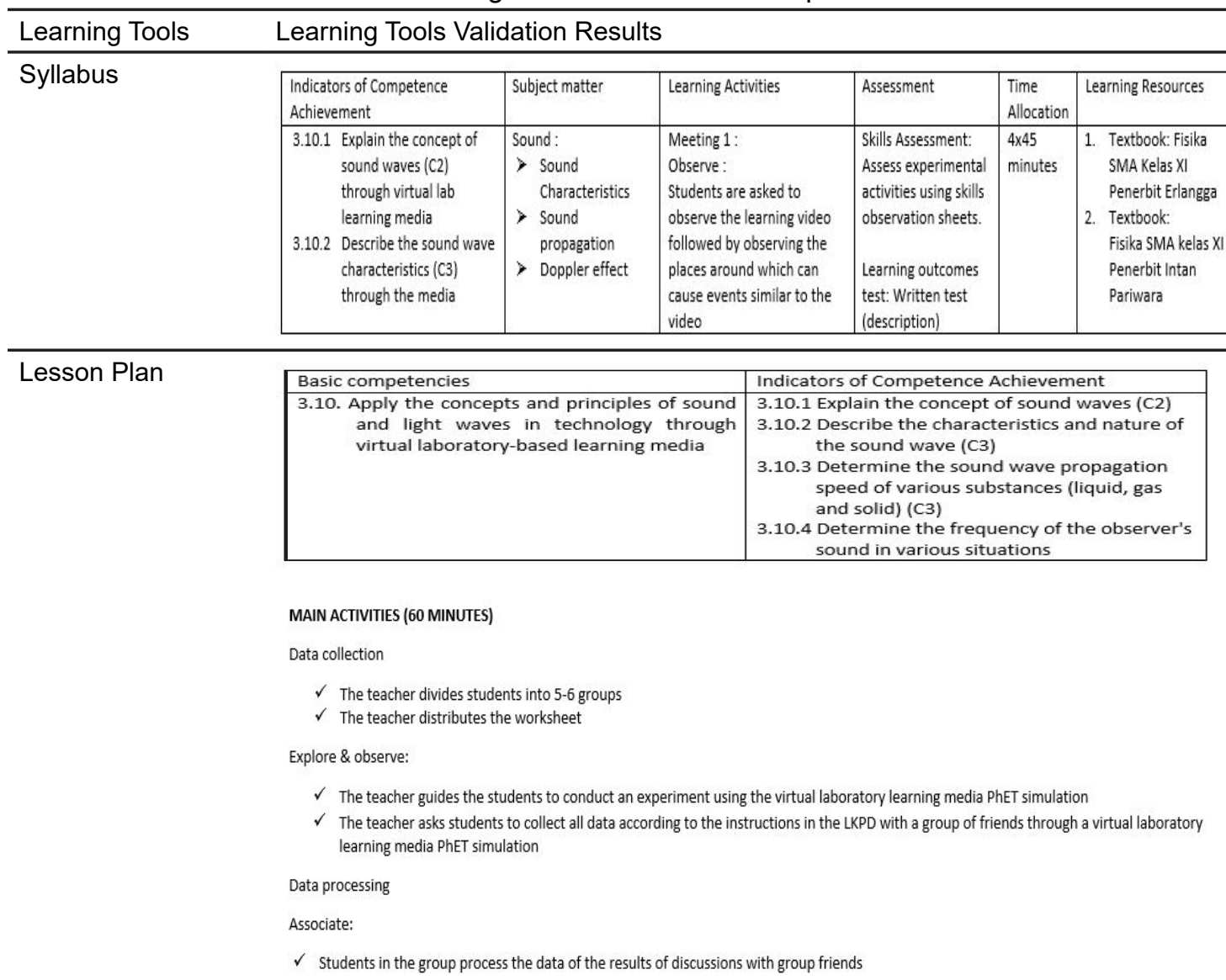


Learning Material

Chapter 1. Learning Media

Basic competencies

1. Applying the concepts and principles of sound and light waves in technology

2. Conduct experiments on sound waves and / or light. Next is the presentation of results and physical meaning, for example, sonometer and diffraction grating

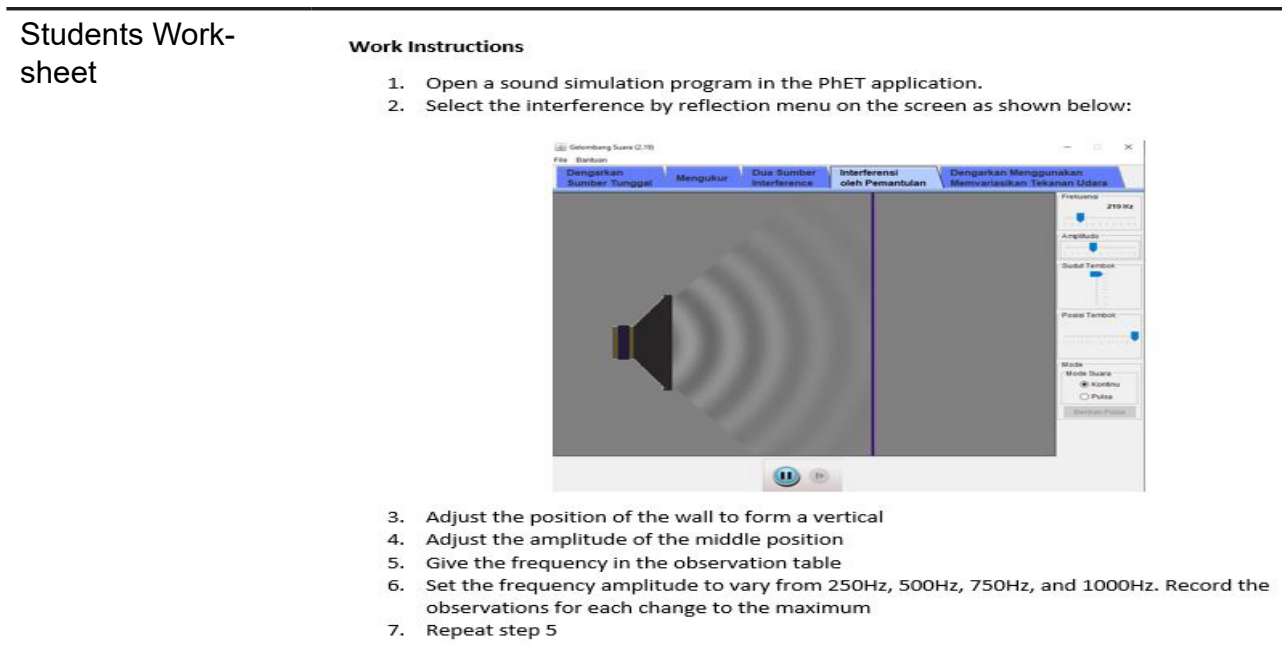

THB

Outline of Learning Outcomes

\begin{tabular}{|c|c|c|c|c|c|c|}
\hline \multirow{2}{*}{ Indicators } & \multicolumn{5}{|c|}{ Number of Items } & \multirow{2}{*}{ Total } \\
\hline & C1 & $\mathrm{C} 2$ & $\mathrm{C} 3$ & $\mathrm{C} 4$ & C5 & \\
\hline Differentiating infrasonic, audiosonic, and ultrasonic & & 1 & & & & 1 \\
\hline $\begin{array}{l}\text { Explain the difference between sound wave } \\
\text { propagation in various substances }\end{array}$ & & 2 & & & & 1 \\
\hline Explain some of the benefits of sound reflectivity & & & 3 & & & 1 \\
\hline Explain the process of echo occurrence & & & & 4 & & 1 \\
\hline Calculate the distance of sound reflection & & & & & 5 & 1 \\
\hline Measuring the depth of the sea & & & & & 6 & 1 \\
\hline
\end{tabular}

Based on the results of the validation in Table 5, it can be concluded that all learning tools based on laboratory, especially virtual sound concepts that have been developed, reach a very valid category. This means, learning tools developed are feasible to be applied to learning physics, to improve student learning outcomes. This is in line with the results of research conducted by Chodijah, Ahmad \& Ratna (2012) that to improve physics learning in the classroom, learning devices such as syllabi, lesson plans, modules and worksheets are needed to support student activities. After the virtual laboratory-based learning tools are validated, the activity is continued with limited trials to obtain data on the practicality and effectiveness of virtual laboratory-based learning tools.

\section{Practicality of Learning Tools}

The practicality of learning tools that have been developed according to Nieven
(1999) can be justified from the results of observations of the implementation of learning in the classroom and the results of student questionnaires after participating in learning.

\section{Implementation of Learning Tools}

In limited trials the implementation of learning is based on the management of teaching and learning activities which include introduction, core activities, and closing. The learning step in the preliminary activity includes the delivery of apperception (this stage is done to explore students' initial knowledge by giving them the opportunity to observe demonstrations conducted by the teacher about the guitar being picked) and conveying the learning objectives.

The next activity is the core activity. In this activity, after the demonstration presentation, students are given the opportunity to formulate problems, express hypotheses, plan virtual laboratory-based activities, carry out 
virtual laboratory-based learning activities, collect data, draw conclusions, and present experimental results in front of the class. The last activity of this learning is closing. In this activity the teacher provides an evaluation to assess the achievement of learning objectives. Data related to the implementation of learning is obtained through an observation sheet observing the implementation of learning that is filled in by the observer and the results are as attached in Figure 1.

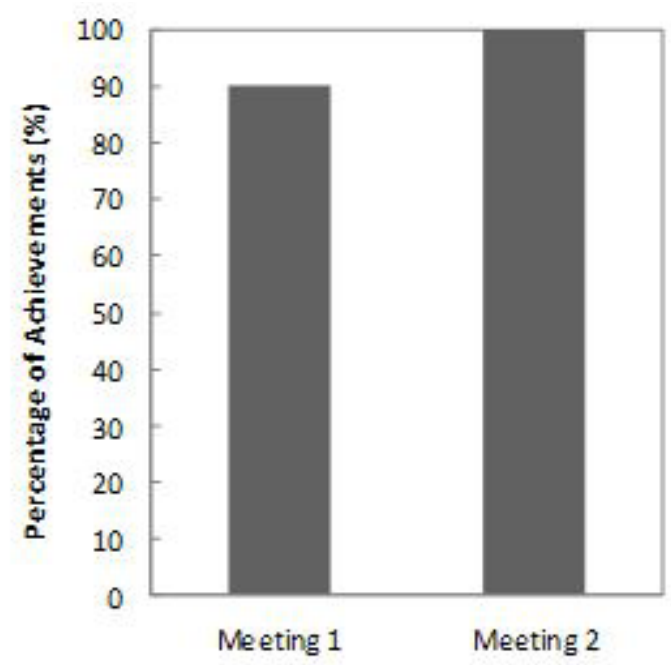

Figure 1. Average Percentage of Implementation of Virtual Laboratory Based Learning

Based on Figure 1, it can be seen that the implementation of virtual laboratory-based learning has been carried out very well as indicated by the average percentage of learning outcomes at both meeting 1 and meeting 2 reaching $95.45 \%$. According to Riduwan (2012), teacher activities can be categorized as actively carried out if the percentage obtained is $61 \%$ with good categories. .

In general the benefits that can be obtained in the use of virtual laboratories are that the learning process becomes more interesting, more interactive, the amount of teaching time can be reduced, the quality of learning can be improved and the teaching and learning process can be done anywhere and anytime (Imron, 2012). This means that, learning based on virtual laboratories can be implemented not only in the classroom, but can also be carried out outside the classroom.

\section{Results of student responses}

Student responses were obtained through a questionnaire instrument given to students after implementing virtual laboratory- based learning and are described in Figure 2 .

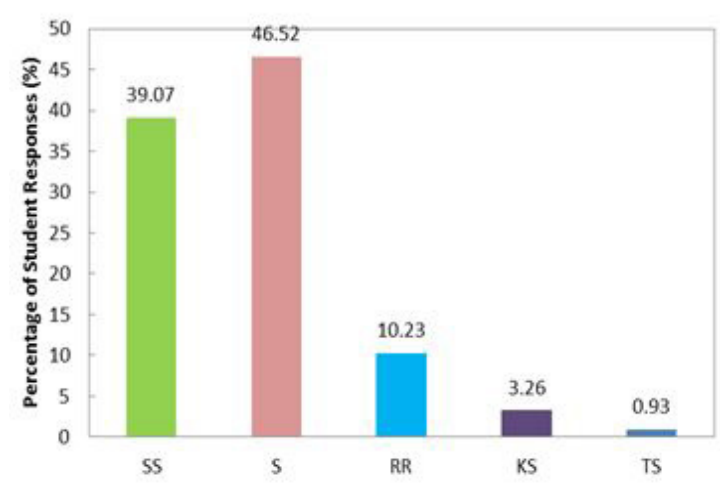

Figure 2. Percentage of Student Responses to Learning Based on virtual laboratories

In Figure 2, it can be seen that students' responses to virtual laboratory-based learning that strongly agree (SS) and agree (S) on average are categorized as very good (85.58\%) compared to the responses of students in doubt $(\mathrm{RR})$, less agree ( KS) and disagreed (TS) average of poor category (14.42\%). According to Riduwan (2012), student responses can be achieved if the percentage obtained is $61 \%$ with good categories. Based on these data it can be concluded that students feel happy, attentive, interested and involved in learning based on virtual laboratories so that they understand the material taught by the teacher. This is because they are directly involved in learning. In learning students are given the opportunity to experience it themselves or do it themselves, follow a process, observe an object, analyze, prove and draw their own conclusions about an object, situation or process (Djamarah and Zain, 2013)

Virtual laboratories as supporting factors play a role in enriching experience and motivating students to conduct experiments interactively and develop experimental skills activities (Tatli and Ayas, 2012). Experimental activities can improve students' creative thinking skills and increase mastery of concepts in physics topics and provide opportunities for students to practice scientific methods (Hermansyah \& Herayanti, 2015). Based on this, it can be concluded that virtual laboratory-based learning tools are practically used in physics learning.

\section{Effectiveness of Learning Devices}

The effectiveness of learning tools can be viewed from two things, namely student learning outcomes and student learning activities as described as follows. 


\section{Student learning outcomes}

The percentage of student learning outcomes that experience virtual laboratory-based learning in each cognitive domain is described in Figure 3.

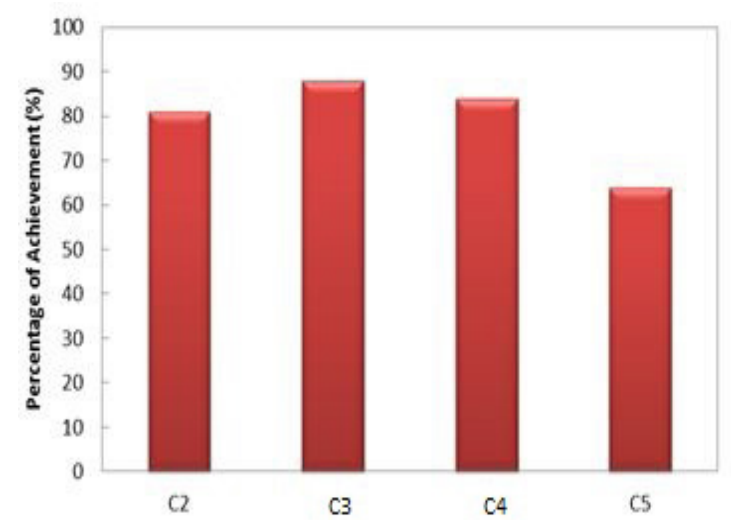

Figure 3. Percentage of Student Learning Outcomes

Based on the results of data analysis, it was found that $75 \%$ of students were declared complete in participating in virtual laboratorybased learning, and $25 \%$ of students were not completed. This is because virtual laboratorybased learning makes students more active in learning, and makes it easier for students to do practical work so students understand the concepts learned. This is in line with the results of research conducted by Hermansyah, Gunawan \& Herayanti (2015) that Virtual Laboratory-based learning has several advantages including increasing student mastery of concept concepts. Virtual laboratory-based learning can improve students' mastery of concepts. The existence of virtual media in the direct learning model can create an active learning process in the classroom (Osman and Kaur, 2014). The results of this study prove the use of virtual laboratories as learning media that has a positive effect on learning outcomes in physics. Learning outcomes are new abilities acquired by students after participating in the teachinglearning process (Widodo, 2013).

\section{Student Learning Activity Results}

Based on observational data, a percentage of student activities is obtained as shown in Table 6.

The data in Table 6 shows that the application of virtual laboratory-based learning tools makes students active in learning, such as active in observing, asking questions, formulating problems, formulating hypotheses, conducting experiments and summarizing experimental re- sults. The use of virtual laboratories can also attract students' attention. Students are more happy and active in receiving subject matter, so they do not demand higher activity from students, because learning activities can arise when there are things that are considered interesting to students, especially the media used are rarely known by students.

Table 6. Percentage of Student Activity

\begin{tabular}{ccc}
\hline Meetings & $\begin{array}{c}\text { Percentage } \\
\text { of Students } \\
\text { Activities }\end{array}$ & Criteria \\
\hline 1 & 80.86 & Very Good \\
2 & 84.86 & Very Good \\
\hline Average Score & 8286 & Very Good \\
\hline
\end{tabular}

Virtual Laboratory-based learning provides opportunities for students to explore, so it is possible for them to always be active (Azis and Yusuf, 2013)

Epinur and Sanova (2014) argued that by conducting virtual laboratories, it was possible for students to carry out experiments as if they were facing real laboratory equipment, so that the expected physics learning objectives would be achieved with lower costs and shorter time. Virtual laboratory learning can be done by reason of limited equipment, time considerations, abstract subject matter, and consideration of the dangers that can be caused if real experiments are conducted in the laboratory.

Based on the findings and analysis conducted, it can be concluded that learning tools based on virtual laboratories are effectively applied in learning physics.

\section{CONCLUSION}

Learning tools that have been developed (syllabus, lesson plans, worksheets, teaching materials and THB) are valid, practical (the implementation of virtual laboratory-based learning devices obtain an average value of 95.45 (very good category). Student responses to virtual laboratory-based learning are average an average of $85.58 \%$ with a very good category which means that virtual laboratory-based learning tools are practically used.This learning is effective as indicated by $75 \%$ of students declared complete participating in virtual laboratory-based learning. This means that learning carried out by teachers in class is effective applied to high school physics learning, especially to the sound concept. 
Based on the results of the study, the researchers suggested that teachers should develop learning tools based on virtual laboratories to overcome various problems that arise in learning physics. These constraints include the majority of tools in the laboratory not functioning properly, the lack of availability of laboratory equipment, and there are some physical material that cannot be practiced directly because it is abstract. In addition, virtual-based learning can be applied so that students understand the material being taught so that student learning outcomes improve.

\section{ACKNOWLEDGMENT}

Acknowledgment addressed to the Directorate of Research and Community Service Directorate General of the Ministry of Research and Technology of the Directorate of Higher Education who have funded this research through applied product research schemes in the 2017 fiscal year according to the contract implementation of research number: 1320 / UN47.D / PL / 2017.

\section{REFERENCES}

Arikunto, S. (2010). Prosedur Penelitian Suatu Pendekatan Praktek. Rineka Cipta. Jakarta.

Azis, A. \& Yusuf I. (2013). Aktivitas dan Persepsi Peserta Didik Dalam Implementasi Laboratorium Virtual Pada Materi Fisika Modern di SMA. Jurnal Berkala Fisika Indonesia, 5(2), 37-42.

Chodijah, St., Ahmad Fauzi \& Ratna Wulan. (2012). Pengembangan Perangkat Pembelajaran Fisika Menggunakan Model Guided Inquiry Yang Dilengkapi Penilaian Portofolio Pada Materi Gerak Melingkar. Jurnal Pendidikan Fisika Indonesia, 1(2).

Djamarah \& Zain. (2013). Strategi Belajar Mengajar. Jakarta: Rineka Cipta.

Epinur, W. S., Sanova, A. (2014). Penerapan Metode Pembelajaran Problem-Based Learning (PBL) Berbantuan Diagram Vee Terhadap Keterampilan Proses Sains Pada Materi Termokimia Berbasis Virtual Laboratorium. Jurnal pendidikan jambi, 16(1), 15-22.

Fathurrohman, Muhammad. (2015). Model-Model Pembelajaran Inovatif. Jogjakarta: Ar-Ruzz Media.

Hermansyah, G. L., Herayanti. (2015). Pengaruh Penggunaan Virtual Laboratorium Terhadap Penguasaan Konsep Dan Kemampuan Berpikir Kreatif Siswa Pada Materi Getaran Dan Gelombang. Jurnal pendidikan Fisika dan Teknologi Mataram, 1(2). ISSN 2407-6902.

Imron, M. (2012). Manfaat Laboratorium Virtual, diakses dari https://mazguru.wordpress. com/2012/04/19/ayomanfaatkanlaboratoriumvirtual, pada 23 Februari 2016 (08:20).

Mademin, I. (2012). Kelebihan dan Kekurangan Model Pengembangan, diakses dari http:// www.ishaqmadeamin.com/2012/12/kelebihan-dan-kekurangan-model pada 11 April 2018.

Nieveen, Nienke. (1999). Design Approaches and Tools in Education and Training. Dordrecht: Kluwer Academic Publishers.

Nurhayati. Fadilah, Syarifah. \& Mutmainah. (2016). Penerapan Metode Demonstrasi Berbantu Media Animasi Software Virtual Labortory Terhadap Hasil Belajar Siswa Dalam MaterListrik Dinamis Kelas X Madrasah Aliyah Negeri 1 Pontianak. Jurnal pendidikan fisika dan aplikasinya (JPFA), 4(2), 2087-9946 (diakses, 3 februari 2016).

Ratumanan, G.T. dan Laurens. (2011). Evaluasi Hasil Belajar Pada Tingkat Satuan Pendidikan. Surabaya: Unesa Unversity Press

Rahmiyati, S. (2008). Keefektifan Pemanfaatan Laboratorium di Madrasah Aliyah Yogyakarta. Jurnal Penelitian dan Evaluasi Pendidikan, 11(1),88-100.

Riduwan. (2012). Skala Pengukuran Variabel-Variabel Penelitian Cetakan IV. Bandung: Alfabeta.

Osman, K \& Kaur, S. (2014). Evaluating Biology Achievement Scores in an ICT integrated PBL Environment. Eurasia Journal of Mathematics, Science and Technology Education, 10(3).

Sondang, N., Nengah M., \& Chandra E. (2014). Pengaruh Kemampuan Inkuiri Terhadap Hasil Belajar Fisika Berbantuan Laboratorium Virtual. Jurnal Pendidikan Fisika FKIP Unila, diakses dari http://jurnal.fkip.unila.ac.id pada 23 januari 2016.

Sugiyono. (2013). Metode Penelitian Pendidikan (Pendekatan Kuantitatif, Kualitatif, dan R \& $D)$. Bandung: ALFABETA.

Sumargo E. dan Yuanita L. (2014). Penerapan Media Laboratorium Virtual (PhET) Pada Materi Laju Reaksi Dengan Model Pengajaran Langsung. Unesa Journal of Chemical Education, 3(1), 119-133.

Sutrisno. (2012). Kreatif Mengembangkan Aktivitas Pembelajaran Berbasis TIK. Jakarta.

Swandi, A. \& Hidayah, N.S., (2014). Pengembangan Media Pembelajaran Laboratorium Virtual Untuk Mengatasi Miskonsepsi Pada Materi Fisika Inti di SMA 1 Binamu, Jeneponto. Jurnal fisika Indonesia, 13(1), 52 diakses dari http://pdm-mipa.ugm.ac.id pada 30 februari 2016.

Syaifulloh, R. B., Budi Jatmiko, B.( 2014). Penerapan Pembelajaran Dengan Model Guided Discovery Dengan Lab Virtual PhET Untuk Meningkatkan Hasil Belajar Siswa Kelas XI Di SMAN 1 Tuban Pada Pokok Bahasan 
Teori Kinetik Gas

Thiagarajan, S, Semmel D.S. \& Sammel, M.J.S. (1974). Instructional development for training teacher of exceptional children a sourcebook. Minnepoli. Indiana University.

Tatli \& Ayas. (2012). Virtual Chemistry Laboratory: Effect of Constructivist Learning Environment. Turkish Online Journal of Distance Education-TOJDE, 13(1), 1302-6488.
Trianto. (2007). Model Pembelajaran Terpadu Dalam Teori dan Praktek. Jakarta: Prestasi Pustaka Publisher.

Widodo. (2013). Peningkatan Aktivitas Belajar dan Hasil Belajar Siswa Dengan Metode Problem Based Learning Pada Siswa Kelas VIIA MTs Negeri Donomulyo Kulon Progo Tahun Pelajaran 2012/2013. Jurnal Fisika Indonesia, 49(18), 32-35. 